Comparative Critical Studies 8.2-3 (201 I): 295-306

Edinburgh University Press

DOI: 10.3366/ccs.20 I I.0024

(C) British Comparative Literature Association

www.eupjournals.com/ccs

\title{
Whose Museum? Whose History? Whose Memories? Remembering in the Work of Dubravka Ugrešić
}

\author{
STIJN VERVAET
}

WRITING EVERYDAY HISTORY: MAKING SENSE OF RANDOM FINDINGS

On the first page of Dubravka Ugrešić's The Museum of Unconditional Surrender (2002) the narrator describes the contents found in the stomach of a walrus named Roland as exhibited at the Berlin Zoo, and suggests that we read the book in the same way we would interpret the objects found in Roland's stomach-as a collection of random archaeological finds that at first glance lack any logical or narrative connection. In other words, we should not expect the novel to provide a well-polished, easy-to-consume chronological narrative, but should be patient and use our imagination to establish semantic connections between chapters and fragments. ${ }^{\mathrm{I}} \mathrm{By}$ invoking the image of a collection of artefacts found in the stomach of a walrus, the narrator introduces the trope of the museum and reminds us that, to reconstruct the past, we often have to rely on artefacts that have survived purely by chance. We have to accept that writing history - for example, the 'life and times' of Roland the walrus - to a large extent means not only preserving and classifying trivial artefacts (as in a museum), but also making sense of these random relics of the past. Asking us to put together the fragments of which the novel is composed, the narrator suggests that we consider the potential of literature and, as becomes clear later in the novel, of contemporary artistic practice to engage creatively with the leftovers of history - because that is what the relics of everyday life very often look like at first glance. ${ }^{2}$

From the very beginning, Ugrešić's narrator points to the role of literature as a mnemonic art-that is, as a way of collecting, preserving, 
displaying and interpreting fragments of the past. In this article, I shall examine how The Museum of Unconditional Surrender not only restages traces of the past in the present, but also reflects upon the content, mechanisms and problems of collective and individual memory. Which motifs and tropes does the novel use to stage the interplay between remembrance and oblivion? What does it tell us about the role that art and literature can (or ought to) play in the construction of individual and collective memory? I will suggest that Ugrešic's novel, by creatively reinscribing the figures of the museum and the archive, and provocatively reminding us of their others in times of enforced collective amnesia, asks us to value the life stories of anonymous people (from Yugoslavia) and to rescue memories of Yugoslav everyday life (without, however, uncritically celebrating it) from the institutionalized waste dump of history.

\section{THE PHOTOGRAPH ALBUM AS FAMILY ARCHIVE}

One of the key motifs in the novel-photography-helps the reader to connect the work's many fragments. The novel consists of seven chapters. The odd-numbered chapters, which have German titles, indicating a simple statement or question - 'Ich bin müde' (I am tired); 'Guten Tag' (Good day); 'Was ist Kunst?' (What is art?); 'Wo bin ich?' (Where am I?) - consist of short textual fragments: conversations or descriptions of encounters. These verbal snapshots are recorded at the time of writing, during the narrator's stay in Berlin. Situated in the diegetic present, these chapters alternate with the longer even-numbered chapters - 'Family museum' (Kucni muzej); 'Archive: six stories with the discreet motif of a departing angel' (Priče s diskretnim motivom andela koji napušta prostor); 'Group photograph' (Grupna fotografija) - which relate stories from the pasts of the narrator, her mother and the narrator's friends. These stories are very often mediated by photographs: the second chapter, which centres on the life of the narrator's mother, begins with the mother classifying her photographs; in the sixth chapter, 'Group photograph', a (blank) photograph triggers the narrator's memories of time spent with seven friends, all female literary scholars, and their last pre-war meeting in Zagreb.

A first version of the museum, the family archive, is, then, the photograph album and its written alter ego, autobiography: photographs are material evidence of the past; they are needed as a basis on which to create a coherent self-narrative. This seemingly prosaic view of 
photography acquires a horrible truth in the anecdote-also mentioned in Ugrešic's I996 essay collection The Culture of Lies $^{3}$ - in the first chapter of The Museum of Unconditional Surrender about the Serbian war criminal Ratko Mladić, who allegedly called a Sarajevan acquaintance to warn him that he had five minutes 'to collect his "albums", because he had decided to blow the house up'. 'The general', concludes the narrator, 'who had been destroying the city for months, knew precisely how to annihilate memory. That is why he "generously" bestowed on his acquaintance life with the right to remembrance. Bare life and a few family photographs' (5). ${ }^{4}$ Photographs are proof of a lost identity, a fact that is bitterly summarized in The Museum of Unconditional Surrender in the refrain of a Bosnian refugee: 'Refugees are divided into two categories: those who have photographs and those who have none' (5 and 228). ${ }^{5}$

Photographs not only help us to recall the past, they can also act as substitutes for past experience. For example, after a trip abroad, the narrator wonders what she would have remembered if she had not taken any pictures. A friend of the narrator pushes it even further: 'Life is nothing other than a photograph album. Only what is in the album exists. What is not in the album, never happened' (25). ${ }^{6}$ As Michael Roth observes, photographs 'seem to offer the possibility of re-experiencing the past, or of experiencing the past without a subjective intermediary', ${ }^{7}$ and the narrator in The Museum of Unconditional Surrender remarks that 'Mother's albums [...] revived before my eyes an everyday life I had forgotten' (2I). ${ }^{8}$ However, the narrator also points to the ambivalence of photographs: they show us something that no longer exists. The photograph of the last kiss with her lover, taken at the airport, ends up being evidence not of their love, but of the relationship's end. Furthermore, photography can represent a phantasm, a reality that never existed, as is revealed by the photomontage of Dorogavtsev (a 'mad' Russian translator of Shakespeare whom the narrator meets in Moscow) posing with Shakespeare. Our memories to a large extent consist of fragments - 'mental snapshots' as well as their material counterpart, 'real' photographs. As the narrator remarks, 'A photograph is a reduction of the endless and unmanageable world to a little rectangle. A photograph is our measure of the world. A photograph is also a memory. Remembering means reducing the world to little rectangles. Arranging the rectangles in an album is autobiography' $(27) \cdot{ }^{9}$

The connection between memory and photography leads the narrator to ponder the similarities between a photograph album and autobiography, the latter being 'a verbal album' (28). ${ }^{10}$ Both the 
compilation of a photograph album and the writing of autobiography are guided by 'the hand of the invisible angel of nostalgia', whose heavy wing 'brushes away the demons of irony' (29). ${ }^{\text {II }}$ As the archivists of our own lives we select, catalogue and classify our literal, mental and verbal pictures, organizing our albums and establishing a certain hierarchy. However, making sense of the (real or imaginary) relics of one's life becomes difficult when society at large decides to reinterpret the past, demanding that one wipe out certain memories and declare the values and experiences of one's generation (or several generations) to be rubbish. This is exactly what happened to memories of everyday life in the former Yugoslavia:

when the names of the streets changed, when the language and the country and the flags and the symbols all changed, when the wrong side became right, and the right side was suddenly wrong, when some people were afraid of their own names, when others, apparently, for the first time weren't afraid of theirs, when people were butchering each other, when some were butchering others; when armies with different insignia sprang up on all sides, when the strongest set out to obliterate everything from the face of their own country, $[\ldots]$ when a lie became the law, and the law a lie; $[\ldots]$ when old myths fell apart and new ones were feverishly created. $(22-23)^{12}$

The impact of this imposed collective amnesia-which in The Culture of Lies Ugrešić fittingly dubs the 'confiscation of memory' (konfiskacija pamcenja $)^{\mathrm{I} 3}$ - is illustrated in The Museum of Unconditional Surrender by the narrator's mother's urge to throw away her dead husband's communist-era medals. Social pressure even makes her consider erasing the red star from her husband's tombstone; however, a sense of shame prevents her from doing so, and, just as she has kept her husband's medals, she eventually decides to keep the photograph of her husband in his partisan uniform: 'It was as though it was then, suddenly confronted with the little star above [her husband's] name that she really accepted her own biography as well' (23). ${ }^{\mathrm{I}}$ To accept one's own biography means accepting that one's life has value, even though it may be declared worthless by the state. The narrator's mother's refusal to go along with the rewriting of history is embodied in her refusal to let the state decide which parts of her past are worthy of being remembered in the private archive that is the family photograph album. However, the album as a depository of memories requires selection, and the difficulty lies in deciding what to save. This brings us to a second important topos of Ugrešić's mnemonic art-rubbish. 


\section{THE ART OF MEMORY AS AN ART OF RUBBISH?}

The word 'rubbish' (smeće) is first used by the narrator's mother, who grumbles that 'all decent people kept their photographs in albums, that it was disgraceful to have all this rubbish [sméce] in the wardrobe, that wardrobes were meant for clothes, and not for all kind of pictures' ( $\left.\mathrm{I}_{5}\right) .^{15}$ However, it is only when her daughter bursts into tears, unexpectedly confronted with a photograph of her recently deceased father, that the mother says 'we ought to buy some albums' (I6). ${ }^{\mathrm{I} 6}$ This traumatic experience shows that 'rubbish' can appear when and where we least expect it, a spectre from the past evoking involuntary memories. ${ }^{17}$

According to Michael Thompson, there are two overt categories of material culture: the durable and the transient. 'Objects in the transient category decrease in value over time and have finite life-spans [the usual state of commodities, we might say]. Objects in the durable increase in value over time and have (ideally) infinite life-spans. ${ }^{, 8}{ }^{8}$ However, ' $[t]$ here are some objects (those of zero and unchanging value) which do not fall into either of these two categories and these constitute a third covert category: rubbish'. ${ }^{19}$ Rubbish exists 'in a timeless and valueless limbo where at some later date (if it has not by that time turned, or been made, into dust) it has the chance of being discovered [...] and transferred to durability'. ${ }^{20}$ In other words, the distinction between transient objects, durable objects and rubbish depends on social factors. ${ }^{21}$ Aleida Assmann transposes this into the language of the archive: something that belongs to the archive can become rubbish, but rubbish can also return to, and be incorporated in, the archive. ${ }^{22}$

The narrator of The Museum of Unconditional Surrender values the rubbish so disliked by her mother. To her, the lady's pigskin bag (which is thrown away by her mother as soon as it loses its practical value) and the wardrobe in which her mother keeps her pictures have an almost sacred value: she describes the latter as 'a treasure-trove of memories', 'the central storehouse of memories' $\left(\mathrm{I}_{4}-\mathrm{I} 5\right) .{ }^{23}$ Furthermore, she is attracted by the flea-markets of Berlin, the city that is the setting for the act of narration. Berlin's biggest hill, the Teufelsberg, consists of rubble and reminds the narrator of 'a walrus that has swallowed too many things' (I60). ${ }^{24}$ By extension, 'Berlin is Teufelsberg, a walrus which has swallowed too many indigestible items' (I6I). ${ }^{25}$ In the words of Richard, one of the artists with whom the narrator frequently meets, and based on the British sculptor Richard Wentworth, 'Berlin is the 
most attractive rubbish heap in the world. Berlin is the world capital of rubbish' (I 66) ${ }^{26}{ }^{26}$ Not unlike the protagonists of the novels of the Russian writer Konstantin Vaginov, ${ }^{27}$ to whom the narrator refers, Wentworth has a passion for the leftovers of the everyday.

The references in the novel to Wentworth and to Ilya Kabakov, the artist who tries to preserve Soviet 6blm (everyday life) from oblivion, and whom the narrator describes as 'the uncrowned king of rubbish' $(37),{ }^{28}$ point to a shared concern with the workings of memory. Both artists use discarded objects in their installations, which invite the viewer to make associations between rubbish and memory. Particularly relevant in this respect is Kabakov's installation The Man Who Never Threw Anything Amay, ${ }^{29}$ a carefully catalogued collection of all kinds of discarded objects, each item with a label explaining where it was found. As Boris Groys has pointed out, by inventing fictitious persons, artists, authors (and their respective biographies) to which he attributed works of art actually produced by himself, Kabakov could 'assume the most divergent artistic attitudes, positions and personal histories, and examine their effects without completely identifying with them'. The technique, also adopted by Moscow conceptualists such as Vitaly Komar and Aleksandr Melamid, is known as 'персонажность' (which might be translated as 'the construction of "characterhood"') and is used not only to undermine any simple identification of artwork and artist, but also to 'shift attention from the production of individual artworks to the context in which they were produced' ${ }^{30}$ Understood as an ironic play with autobiography and fiction, which draws attention to the social and (art-) historical context in which the work of art is created, 'персонажность' has much in common with the ironic play in The Museum of Unconditional Surrender and another of Ugrešić's works, The Ministry of Pain (2004). ${ }^{3 \mathrm{I}}$

The reflections of Kabakov's fictional character on rubbish make clear that his urge to collect and catalogue is fuelled by 'the impossibility to separate the important from the unimportant', an inability to understand 'why one principle of selection is better than another, and what distinguishes a pile of necessary papers from a pile of garbage'. Kabakov's 'rubbish man' (мусорный человек) is mesmerized by litter on account of 'the memory associated with all the events connected to these papers. $[\ldots]$ To deprive ourselves of this means to part with who we were in the past, and in a certain sense, it means to cease to exist'. ${ }^{32}$ Ironically asking why common sense (which urges us to distinguish between the valuable and rubbish, and to discard the latter) should prevail over the sentimental value of his personal memories, he concludes that it is precisely the 
garbage, that very dirt where important papers and simple scraps are mixed and unsorted, that comprises the genuine and only real fabric of my life, no matter how [...] this might seem from the outside'. ${ }^{33}$ As we have seen, Ugrešić's narrator is equally intrigued by the mechanisms of selection and by the emotional value ordinary objects can possess. The less obvious forms of rubbish in The Museum of Unconditional Surrender can all be seen to have the kind of meaning Kabakov's 'rubbish man' finds in discarded objects. For example, one of the narrator's most cherished childhood memories is connected with the scraps of material the children used to get from the 'Singer-duchess', the seamstress from the small town in which the narrator grew up. Similarly, the spelling mistakes, misused words, wrong case endings, clichés and superfluous exclamation marks she erases when editing her mother's diary actually reveal (at least, to her) the identity of her mother in a much more direct and painful way than the 'edited' diary does.

By drawing attention to the excluded, marginalized or suppressed, art that incorporates rubbish shows us the other face of the subject - be it the collective subject, as represented by official historiography and memory politics, or the individual, as embodied in the photograph album and the autobiography. As Aleida Assmann puts it: 'solche Kunst macht das schlechthin unsichtbare, nämlich die Grundstrukturen kultureller Wert- und Unwert-Produktion sichtbar' (such art renders visible the absolutely invisible, namely the underlying structures of the production of cultural value and non-value). ${ }^{34}$ The conviction of Kabakov's rubbish man that 'things once used by someone [...] did not become something dead when they were discarded. They cry out about a past life', 35 also seems to be shared by Richard Wentworth. Arranging and assembling in his installations all kinds of discarded domestic and industrial objects into new forms and shapes, or photographing them in unusual settings, Wentworth defamiliarizes our perception of the leftovers of commodity culture. Thus, not only does he reveal 'a secret history of the quotidian', but he also invests found objects with new meaning. ${ }^{36}$ Ugrešic's narrator is particularly intrigued by the way in which Richard cares for the objects he finds and how in his hands they almost become living beings. He makes clear that, more than mere preservation of the past, 'remembering is also an act of love'. ${ }^{37}$

Ugrešić, however, takes Wentworth's 'remembering as an act of love' a step further by drawing the reader's attention to the ethics of remembering. She does so by touching upon Christian Boltanski's project The Missing House, which draws attention to the traces of those 
who disappeared in the Holocaust. ${ }^{38}$ Juxtaposing Boltanski's rows of cardboard boxes containing the photographs of anonymous people with the photographs and 'souvenirs of a vanished everyday' that Yugoslav refugees sell at Berlin flea-markets, she reminds the reader of the 'human rubbish', those who by chance have survived the flood of history: the war in Yugoslavia, the introduction of the free market in Eastern Europe. Thus, the Berlin of Ugrešic's novel is not only a city of museums, ruins and rubbish, but also a city of refugees ${ }^{39}$ - people who inhabit the limbo between a country that no longer exists and a new society which has yet to accept them. One of the narrator's Yugoslav friends, Zoran, remarks several times that 'all of us here are museum exhibits' (22I). ${ }^{40}$ At the same time, however, their very existence negates the concept of the ethnically cleansed nation-state that was the dream of the policy-makers in the former Yugoslavia in the I990s. Just as Richard collects 'abandoned chairs' from the streets of Berlin ( $\mathrm{I} 64$ ), or 'saves plates from ruin' (I62), ${ }^{4}$ investing them with new meaning, and Christian Boltanski reconstructs anonymous human lives, Ugrešić's narrator saves from oblivion the life stories of refugees from the former Yugoslavia, including those of the mother of the Bosnian refugee Kašmir and, indeed, her own mother.

\section{FROM THE CONFISCATION OF MEMORY TO THE WRITING OF COUNTER-MEMORY}

The Museum of Unconditional Surrender reveals Ugrešićs fascination with rubbish as the embodiment of the other of both the museum and the private archive. By focusing on rubbish,$^{42}$ she points to the many faces of oblivion: (I) the leftovers of history: the hidden ruins on which Berlin is built, but also the everyday events and stories that do not become part of institutionalized memory or that are neglected or erased by official historiography; (2) the leftovers of autobiography: elements that are erased by the censor (or silenced by auto-censorship, as when the narrator's mother classifies her photographs, or when the narrator 'edits' and 're-tells' the diary of her mother); (3) the leftovers of consumer society: the artefacts used by artists in their installations, the stuff of the flea-markets; (4) the leftovers of the post-communist condition: refugees from the former Yugoslavia and other Eastern European countries. If we understand rubbish as something that escapes the mechanisms of control (official historiography, museums, memory politics, elite art, autobiography, private archives such as the photograph album), then elevating rubbish to the level of art becomes a way of creating a counter-memory. 
Bringing to the foreground artefacts that are no longer useful, and incorporating them into stories, not only denies or subverts the laws, norms and hierarchies of a given society, but also reveals how the social system works. In times of collective amnesia, literature and art can play an important mnemonic role, saving 'discarded' memories. Unlike her friends, who, touched by the angel Alfred's 'little feather of oblivion', have forgotten the past, Ugrešic's narrator is bestowed with 'the gift of memory' ${ }^{43}$ However, she does not seem particularly happy with such a restricted definition of literature: not remembering reality, she complains, but 'the invention of reality is the job of real literature' $(2 \mathrm{I} 6) .{ }^{44}$

The narrator's concern for the leftovers of the Yugoslav everyday - the scraps of the seamstress, the photograph albums and 'ordinary' life stories such as those of her mother and other refugees in Berlin - is more than merely a reaction to grand narratives proposed by the historians, archivists and curators of Croatia. Ugrešić's novel also shows that any memory politics - whether private or collective - unavoidably means selection, exclusion and oblivion, suggesting that there will always be 'rubbish' that escapes the institutionalized mechanisms of remembrance. It thus comes as no surprise that her work should have been declared to be 'rubbish' by nationalist Croatian literary critics in the early i 990 os. Ultimately, The Museum of Unconditional Surrender resembles one of the objects found in the stomach of Roland the walrus: indigestible for the engineers of nationalist memory politics, it points beyond all official archives.

\section{NOTES}

I See Dubravka Ugrešić, Muzej bezuvjetne predaje (Zagreb: Kondor; Belgrade: Samizdat B92, 2002), p. I I; translated by Celia Hawkesworth as The Museum of Unconditional Surrender (New York: New Directions, I999), p. xi. Further references to the English translation are given in the main text of the article; references to the Croatian original follow the quotations in the footnotes.

2 It is important to bear in mind, however, that archaeologists have often learned at least as much about the everyday life of common people from their rubbish as from the 'valuable' artefacts they leave behind.

3 Dubravka Ugrešić, Kultura laži (Zagreb: Kondor; Belgrade: Samizdat B92, 2002); translated by Celia Hawkesworth as The Culture of Lies (London: Phoenix House, I998).

4 'obavijestio ga da mu daje pet minuta da pokupi “albume”, jer je, kaže, baš namjerio da mu digne kuću u zrak'; 'Zločinac, koji je mjesecima rušio grad, biblioteke, spomenike, crkve, ulice i mostove, znao je da uništava pamćenje. Zato je svom znancu 
"velikodušno" poklonio život s pravom na pamćenje. Goli život i nekoliko obiteljskih fotografija' ( 18 ).

5 'Izbjeglice se dijele na dvije vrste: na one s fotografijama i na one bez fotografija' ( 8 and 290).

6 'Život i nije drugo do album s fotografijama. Samo to što je u albumu postoji. To čega u albumu nema, nikada nije ni postojalo' (42).

7 Michael S. Roth, 'Photographic Ambivalence and Historical Consciousness', History and Theory 48 (2009), 82-94, this quotation p. 86.

8 'Mamini albumi [...] oživjet će pred mojim očima svakidašnjicu koju sam bila zaboravila' (37).

9 'Fotografija je svođenje beskrajnog i nesavladivog svijeta na kvadratić. Fotografija je naša mjera svijeta. Fotografija je i uspomena. Pamćenje je svođenje svijeta na kvadratiće. Uvrštavanja kvadratića u album je autobiografija' (45).

Io 'autobiografija je verbalni album' (45).

I I 'Album i autobiografija djelatnosti su vođene rukom nevidljivog anđela nostalgije. Svojim teškim krilom anđeo nostalgije otpuhuje đavole ironije u stranu' (47).

I2 'kada su se promijenili nazivi ulica, kada se promijenio jezik i zemlja i zastave i simboli; kada su se promijenili nazivi ustanova, škola, vlakova i aviona; kada je kriva strana postala prava, a prava naglo kriva; kada su se jedni pobojali vlastitih imena, kada ih se drugi prvi put nisu bojali; kada su kasapili jedni druge, kada su jedni kasapili druge; kada su prokuljale vojske s različitim oznakama, kada je prokuljala najjača da sve zatre s lica svoje zemlje; [.. ] kada je laž postala zakon a zakon laž; [...] kada su se raspadali stari mitovi i u vrućici stvarali novi' (38-39; Ugrešić's emphasis).

I3 Ugrešić, Kultura laži, pp. 273-293; pp. 2 17-235.

I4 'Kao da je tada, iznenada suočena s malom petokrakom iznad muževljeva imena, prvi put zaista pristala i na vlastitu biografiju' (39).

I5 'da svi pristojni ljudi imaju albume za fotografije, da je sramota da se sve to smeće nalazi u ormaru, da je ormar, uostalom, mjesto za odjeću a ne za kojekakve slike' (30).

I6 'Morali bismo kupiti albume' (30).

I7 Cf. Joe Moran, 'History, Memory and the Everyday', Rethinking History 8 (2004), $5 \mathrm{I}-68$, especially p. 65.

I 8 Michael Thompson, Rubbish Theory: The Creation and Destruction of Value (Oxford: Oxford University Press, I979), p. 7.

I9 Ibid., p. 9.

20 Ibid., p. го

2I Ibid., pp. 8-I2; cf. Moran, 'History, Memory and the Everyday', p. 64.

22 See Aleida Assmann, Erinnerungsräume. Formen und Wandlungen des kulturellen Gedächtnisses (Munich: Beck, I999), p. 383: 'Das Archiv, das eine Sammel- und Konservierungsstelle für das Vergangene, aber nicht zu Verlierende ist, kann als ein umgekehrtes Spiegelbild zur Mülldeponie betrachtet werden, auf der das Vergangene eingesammelt und dem Zerfall überlassen wird. Archiv und Müll sind aber nicht durch eine gemeinsame Grenze miteinander verbunden, die von Gegenständen in beiden Richtungen überschritten werden kann. Was nicht ins Archiv kommt, landet auf der Mülldeponie; und was im Archiv von Zeit zu Zeit aus Platzmangel aussortiert wird, landet ebenfalls dort. Aber auch manches, was heute im Archiv lagert, befand sich zwischenzeitlich [...] im Status des Abfalls' (The archive-a repository for obsolete objects that nevertheless warrant 


\section{Remembering in the Work of Dubravka Ugrešić}

preservation - can be thought of as the inverse reflection of the rubbish dump, on which the obsolete is piled and left to decay. Archive and rubbish, however, are not connected by a common border, which objects are able to cross in either direction. Things that do not make it into the archive end up on the rubbish dump, as do those which from time to time are culled from the archive owing to lack of space. Yet there are also objects today housed in the archive which at one time $[\ldots]$ had the status of rubbish') (my translation, in collaboration with David Williams).

23 'ostava za uspomene' (28); 'centralno skladište uspomena' (30).

24 'Teufelsberg sliči morskom slonu koji je progutao previše stvari' (209).

25 'Berlin je poput morskog slona koji je progutao previše neprobavljivih stvari' (2 Io).

26 'Berlin je najprivlačnije smetlište na svijetu. Berlin je svjetska prijestolnica smeća' (2 I6).

27 On the topic of collecting, which is central to the work of Konstantin Vaginov, see Antony Anemone, 'Obsessive Collectors: Fetishizing Culture in the Novels of Konstantin Vaginov', Russian Reviem 59 (2000), 252-268.

28 'taj neokrunjeni kralj smeća' (57).

29 This installation was first presented in the West in 1988 as part of the series Io Characters, which Kabakov created in his Moscow studio between I97I and 1976.

30 Boris Groys, 'The Movable Cave of Kabakov's Self-Memorials', in Ilya Kabakov, edited by Boris Groys, David A. Ross and Iwona Blazwick (London: Phaidon Press, I 998), pp. 30-79, this quotation p. 35. Ugrešić and Kabakov share a fascination with the work of Gogol. According to Groys, Kabakov's work is 'more deeply grounded in the Russian classics of the nineteenth century than in the history of visual art' (ibid., pp. 44-45). For a fine analysis of a Gogolian intertext in Ugrešić's earlier work, see Lauren Lydic, “ "Noseological” Parody, Gender Discourse, and Yugoslav Feminisms: Following Gogol's "Nose" to Ugrešić's "Hot Dog on a Warm Bun”, Comparative Literature 62 (2010), I6I-I 78.

3I Dubravka Ugrešić, Ministarstvo boli (Zagreb: 90 Stupnjeva, 2004); translated by Michael Henry Heim as The Ministry of Pain (London: Saqi, 2005).

32 Ilya Kabakov, 'The Man Who Never Threw Anything Away', in Ilya Kabakov, pp. 98-I05, this quotation p. Ioo.

33 Ibid., p. гог.

34 Assmann, Erinnerungsräume, p. 384 (my translation).

35 Kabakov, 'The Man Who Never Threw Anything Away', p. Io2.

36 See Michael Bracewell, “"So Much Depends”: An Introduction to the Art of Richard Wentworth'. The text is available on the Lisson Gallery website, which also features images of representative works by Wentworth.

37 'to je, zapravo, ljubavni posao' (2 I4).

$3^{8}$ On Christian Boltanski's project The Missing House, see Monika Wagner, 'Bild-Schrift-Material. Konzepte der Erinnerung bei Boltanski, Sigurdsson und Kiefer', in Ähnlichkeit und Entstellung im Verhältnis der Künste, edited by Birgit R. Erdle and Sigrid Weigel (Cologne, Weimar and Vienna: Böhlau, r996), pp. 23-39.

39 Her story of Berlin is knitted together with quotations from the work of other exiles who once resided in the city, including Viktor Shklovsky and Vladimir Nabokov, and of passers-through such as Miroslav Krleža. One might read the narrator's frequent use of quotations and frequent repetition of key fragments as a way of retelling or 
recycling, the 'нанизывать' to which Kira, the retired literature teacher from Kiev, refers at the beginning of the novel.

40 'Svi smo mi ovdje muzejski eksponati' (28I).

4I 'odbačene stolice' (2 I4); 'svoje tanjure spašava od propadanja' (2 I 2).

42 English has many more synonyms for rubbish (trash, litter, garbage, junk, debris, scrap, etc.) than does Croatian. While Ugrešic mainly uses the term 'smeće' when referring to 'normal' rubbish, she also uses many other words to indicate the variety of discarded objects her narrator describes, from neutral words such as 'predmeti' (objects) and 'stvari' (things), to more specific ones such as 'neprobavljive stvari' (indigestible things - in Roland's stomach), 'ruševine' (ruins), 'smetlište' (rubbish dump), 'obično đubre' (ordinary rubbish), 'sitni otpaci' (scraps of rubbish), 'papirići' (scraps of paper), 'tričarije' (trifles), 'trivijaliteti' (trivialities), 'opušci' (cigarette butts), 'najrazličitije smeće' (the most varied rubbish), 'čađa' (soot-from the soot factory in the town where the narrator grew up) and 'krpice' (scraps of material - used by the seamstress). Describing the stylistic imperfections of her mother's diary, the narrator chooses words with a more emotional or poetic connotation: 'ti slatki mali uskličnici' (those endearing little exclamation marks), 'ljuskice njezina jezika' (the tiny shells of her language).

43 In addition to this nod to Walter Benjamin's Angel of History, topoi such as everyday life, collecting practices and the aesthetics of rubbish all link the novel to Benjamin's œuvre. For a reading of angel Alfred in the context of Benjamin's 'Theses on the Philosophy of History' (I940), see Monica Popescu, 'Imagining the Past: Cultural Memory in Dubravka Ugrešic's The Museum of Unconditional Surrender', Studies in the Novel 39 (2007), 336-356, and for a detailed analysis of the overall Benjaminian intertext in Ugrešić's Museum, see Vladimir Biti, Doba svjedočenja. Tvorba identiteta u suvremenoj hrvatskoj prozi (Zagreb: Matica hrvatska, 2005), pp. 225-24I.

44 'jer izmišljanje stvarnosti i jest posao prave književnosti' (275). 